\title{
KENDALA ORANGTUA DALAM MENDAMPINGI ANAK BELAJAR PADA MASA COVID 19
}

\author{
IKHA AYU SULISTYARINI \\ MTs Negeri 1 Yogyakarta \\ Email: ikhaazmaira@gmail.com
}

\begin{abstract}
ABSTRAK
Pandemi covid-19 semakin meningkat di Indonesia dengan temuan baru varian Delta yang mengakibatkan banyak orang meninggal terpapar covid-19 sehingga belajar daring oleh pemerintah diperpanjang sehingga membuat perubahan pada semua aspek pendidikan . Penelitian bertujuan untuk mengetahui tentang kendala yang dirasakan oleh para orang tua saat mendampingi atau memberi arahan anaknya belajar di rumah. Jenis penelitian ini menggunakan metode deskriptif, dengan melalui teknik wawancara, observasi,simak Dalam penelitian ini mampu menghasilkan dan menunjukan gambaran secara umum yang dialami oleh para orang tua dalam mendampingi anak belum maksimal belajar di rumah dimasa covid-19 yang sangat luar biasa banyak menguras tenaga,emosi, waktu, kuota, jaringan internet, bahkan para orang tua sangat mengeluh dengan belajar yang diberikan secara virtual googlemeet atau yuotube serta materi yang menggunakan media seperti,whatshap, Google Class Room,Geschool,Gmeet dilanjutkan dengan evaluasi dan tugas, akhirnya menimbulkan kegelisahan orang tua yang belum paham dengan materi yang diajarkan yang disampaikan lewat daring di kelas IXG.Di masa pandemi peran serta orang tua sangat penting dalam mendukung keberhasilan prestasi anak. Para guru di sekolah dimohon agar belajar dari rumah dan di titik beratkan pada materi yang esensial dan tugas-tugas tidak memberatkan serta berbasis aktivitas rumah. Teknologi (media pembelajaran) seperti menggunakan HP android, laptop, gadget. Hal ini mengakibatkan keresahan dan kebingungan para orang tua yang memiliki latar belakang pendidikan yang berbeda. Dengan motivasi yang kuat dan membuat inovasi baru dalam membimbing anak, agar anak tidak jenuh dan stres dalam belajar, harus adanya kordinasi dan komunikasi yang baik antara orang tua dan guru. Diperlukan evaluasi agar bisa meningkatkan hasil prestasi siswa.
\end{abstract}

Kata kunci : Belajar, COVID-19, Kendala Orang tua

\section{PENDAHULUAN}

Virus covid 19 atau corona yang dengan cepat menyebar, membuat perubahan aktivitas dari berbagai sektor kehidupan manusia saat ini. Dengan mengikuti himbaun dari pemerintah serta taat adalah salah satu cara menghindari dan mensiasati agar tidak tertular virus corona. Salah satu bidang yang menjadi perhatian khusus adalah pendidikan. Proses pendidikan pada masa pandemi mengharuskan pembelajaran dari rumah disebut daring. Berbagai macam permasalahan baru muncul. Menanggapi hal tersebut, pemerintah mengambil kebijakan akan hal ini dengan mengganti pembelajaran dengan cara daring.

Diharapakan dengan kebijakan itu semua lembaga pendidikan untuk merubah sistem pembelajaran, sehingga meminimalisasi penyebaran virus tersebut. Hal ini juga dilakukan oleh berbagai negara yang terpapar wabah ini, kebijakan lockdown atau karantina atau PPKM (Pemberlakuan Pembatasan Kegiatan Masyarakat) dilakukan sebagai usaha meminimalisisr interaksi yang melibatkan banyak orang sehingga adanya akses pada penyebaran virus corona. adanya virus corona pada mulanya begitu berdampak pada aspek ekonomi yang semakin rendah, namun kini dampaknya masuk ke dunia pendidikan. Kebijakan yang dilakukan oleh berbagi pemerintah dengan memberlakukan pembelajaran daring, mengaharuskan pemerintah dan lembaga terkait harus membuat sebuah proses pembelajaran yang inovatif agar peserta seluruh kalangan sisiwa dan mahaisiswa tetap dapat melakukan proses pembelajaran dengan baik. Berkaitan dengan hal itu pembelajaran daring adalah solusi alternatif dalam pembelajaran pada saat pandemi covid-19. 
Berbagai kemudahan proses pembelajaran ini, tidak lepas dari adanya kesulitan ataupun kendala kendala. Seperti halnya peran orang tua sangat penting agar anak dapat tetap semangat, dan tidak merasa tertekan. Bahkan proses pembelajaran di rumah tetap menyenangkan. Adanya pembelajaran daring tentu terdapat berbagai kendala, mulai dari kuota internet, sinyal yang jelek, hp bergantian dengan saudara atau orang tua, dan sebagainya. pembelajaran daring tak lepas dari peran orang tua untuk mengawasi anaknya masing-masing. Orang yang sibuk bekerja, kurang perhatian atau susah dalam membimbing anaknya, merupakan masalah baru pada pembelajaran saat ini. Peran serta orang tua memberikan dampak yang besar, karena para orang tua dituntut mampu mengawasi anaknya pada saat pembelajaran. Pada dasarnya setiap anak memiliki potensi yang tidak terbatas. Tetapi ada beberapa faktor yang dapat mempengaruhi apakah mereka pada akhirnya memenuhi potensi itu. Para ahli percaya bahwa peran orangtua dalam kehidupan anak memiliki dampak yang luas.

Keterlibatan orangtua sangat penting bagi anak anak untuk berprestasi di sekolah. Beberapa orangtua berpikir bahwa belajar adalah peran guru untuk mengajar, bukan peran mereka. Tetapi kepercayaan seperti itu tidak merugikan orangtua dan anak-anak. Anak-anak tidak memulai dan berhenti belajar hanya selama hari sekolah. Mereka selalu terbiasa dengan belajar, di rumah, dengan teman, dan melalui pengaruh lain. Sebagian orang tua berpendapat bahwa pendidikan adalah suatu hal yang utama, atau penting. Semakin berkembangnya zaman masyarakat menyadari akan pentingnya pendidikan. Sehingga dengan keadaan pandemi seperti ini, orang tua tetap berusaha memberikan yang terbaik bagi anaknya. Oleh karena itu peran orang tua menjadi sangat penting dalam tercapainya tujuan belajar, hal itu dengan cara memberi bimbingan dan pendampingan yang terbaik pada saat pembelajaran berlangsung. Selain hal itu bimbingan dalam setiap harinya juga tidak kalah penting untuk dilakukan.

Memberikan pendidikan karakter kepada anak sejak dini tentu akan sangat berdampak besar bagi perkembangannya. Sudah diterapkannya pendidikan karakter setiap harinya, tentu anak akan menjadi lebih bersemangat dalam belajar meskipun dilakukan di rumah. Tingkat kepercayaan diri mengikuti proses belajar. Sehingga kecrdasan anak meningkat dan hasil belajar dapat sesuai dengan yang diharapkan. Proses pembelajaran yang dilakukan secara daring yang disiapkan oleh guru melalui Whatsapp, Gmeet, Google Clasroom, Email, Zoom atau aplikasiyang lainya dan sesuai arahan pemerintah. Pada hal ini orang tua diharuskan memastikan anak tersebut melaksanakan proses pembelajaran dengan baik di rumahnya.

Proses ini juga dapat membatasi kegiatan di luar rumah, berkoordinasi dengan guru mata pelajaran, memberikan edukasi kepada siswa menerapkan pola hidup bersih sehat (PHBS) dan 5M di rumah dan lain sebagainya. kegiatan pembelajaran di rumah, dapat dilakukan dengan guru memberikan bahan materi untuk dipelajarai, dan terdapat berbagai tugas yang harus diselesaikan. Jika dalam beberapa hal yang kurang dipahami dapat dikonsultasikan oleh guru tersebut. Kegiatan ini dilakukan dengan menggunakan media belajar online yang telah disepakati sebelumnya (Wardhani, 50:2020).

Berkaitan dengan hal tersebut khususnya di kelas IX G MTs Negeri 1 Yogyakarta yang secara umum orang tua tidak banyak yang berpendidikan tinggi, tentu kesulitan dalam hal ini. Apalagi ada beberapa orang tua yang harus bekerja diluar, hal ini sangat berpengaruh dalam kecerdasan anak. Selain masalah tersebut, jaringan internet menjadi kendala yang membuat proses pembelajaran menjadi terhambat.

Berbagai kendala tersebut perlunya konfirmasi antara guru, siswa, dan orang tua yang baik agar proses pembelajaran yang dilakukan di rumah dapat berjalan sesuai yang diharapkan. Penelitian terdahulu yang serupa yaitu dilakukan oleh lutifah (2020) dengan judul Persepsi Orang Tua Mengenai Pembelajaran Online di Rumah Selama Pandemi covid19, hasil penelitian tersebut antara lain: orang tua berpandangan kurang baik diantaranya kurang adanya sarana dan prasarana, sebagian orang tua kurang siap mendampingi anak untuk pembelajaran daring. Selain itu hal positifnya yaitu melatih siswa menjadi bertanggung jawab, mandiri, selain itu guru dapat mengembangkan cara pembelajaran yang inovatif dan kreatif. 
Adapun yang lain yaitu penelitian yang dilakukan Khadijah dan Gusman (2020) dengan judul Pola Kerja Sama Guru dan Orang Tua Mengelola Bermain Anak Usia Dini Selama Masa Pandemi Covid-19. Hasil penelitiannya adanya empat konsep kerjasama yaitu kerjasama sebagai guru fasilitator, pendamping, Kerjasama sebagai, Kerjasama menciptakan pembelajaran jarak jauh yang menyenagkan. Beberapa hal yang kurang baik akan proses pembelajaran ini yaitu kurangnya pemahaman terkait pemanfaatan teknologi, orang tua memiliki kesibukan dalam bekerja, kurangnya pemilihan media bermain yang sesuai dengan kondisi. Beberapa penelitian terdahulu dapat disimpulkan bahwa adanya pandemi covid19 menimbulkan beberapa kendala akan proses pembelajaran. Selain siswa, guru, orang tua juga juga memiliki dampak yang besar, diantaranya faktor bagaimana kendala yang dihadapi orang tua dalam membimbing anaknya pada proses pembelajaran di rumah (daring) serta bagaimana peran orang tua ketika membimbing anaknya pada saat pembelajaran daring.

Penelitian ini bertujuan menemukan berbagai kendala yang dihadapi orang tua dalam membimbing anaknya pada proses pembeljaran di rumah (daring) dan dapat mendeskripsikan peran orang tua dalam membimbing anaknya pada saat pembelajaran daring. Sehingga dapat memberikan kontribusi agar masyarakat, khusunya orang tua, guru, dan sisiwa dapat mengetahui berbagai macam kendala dan peran terkait pembelajaran daring yang maksimal serta dapat menjadi referensi ataupun koreksi bagi peneliti selanjutnya dan dapat dikembangkan bagi penelitian yang sejenis

\section{METODE PENELITIAN}

Penelitian ini menggunakan metode adalah metode deskriptif kualitiatif. Metode ini merupakan metode yang berupaya untuk menggambarkan atau menjelaskan tentang suatu gejala sosial. Metode ini digunakan guna mendapatkan informasi yang lebih kompleks, sehingga informasi yang didapat lebih banyak dan dapat berguna bagi perkembangan ilmu yang sejenis. Dengan kata lain tujuan dari metode kualitatif deskriptif ini yaitu untuk memberikan kajian yang komprehensif dan mendalam berkaitan dengan kondisi atau fenomena yang terjadi dalam kehidupan sehari-hari atau dari peristiwa spesifik yang dialami oleh individu atau kelompok individu (Sarwono, 2006).

Selanjutnya pengumpulan data, pengumpulan data yang digunakan adalah observasi, wawancara, dan simak. Ketiga teknik tersebut sifatnya saling melengkapi. Observasi adalah kegiatan yang dilakuakn peneliti untuk mendapatkan informasi yang diperlukan, guna memenuhi dan mendukung proses penelitian. Hal ini juga dapat sebagai sarana evaluasi untuk mengukur data dan fakta hasil observasi di lapangan. Hasil observasi dapat berupa kejadian, peristiwa, kondisi, dan hal lain sesuai dengan peneitian tersebut (Sujarweni, 2014:75).

Teknik pengumpulan data selanjutnya yaitu wawancara. Wawancara menururt Sujarweni (2014:31) yaitu kegiatan untuk mendapatkan informasi yang sudah ditelaah atau dipersiapkan sebelumnya dengan berbagai teknik. Teknik tersebut ada dua yaitu bisa dilakukan dengan tatap muka maupun menggunakan media (tidak secara langsung). Kegiatan wawancara ini dilakukan lebih mendalam, agar informasi yang ingin didapat benar-benar valid dan sesui dengan keadaan. Setelah itu dilanjutkan menggunakan teknik simak yang dilengkapi dengan teknik catat. Teknik simak dilakuakn dengan menyimak informasi atau objek penelitian (Sudaryanto 1993:41). Pada penelitian ini menyimak tentang tuturan orang tua murid terkait kendala dan peran pembelajaran pada masa pandemi. Agar mempermudah data penelitian, pada pengumpulan data dibantu dengan teknik catat. Pada penelitian ini yaitu mencatat hal penting yang berkaitan dengan ruang lingkup penelitian.

\section{HASIL DAN PEMBAHASAN}

Pembelajaran di masa pandemi covid-19 Di MTs Negeri 1 Yogjakarta dilakukan secara daring, dengan berbagai cara yang dilakukan oleh guru. Baik melaui whatsap, google clasroom, geschool, e learning madrasah dan sebagainya. Berkaitan dengan itu tentu terdapat kontroversi. Terlebih kondisi orang tua yang tidak memungkinkan untuk selalu mengawasi anakya dalam 
belajar, menimbulkan tidak efektifnya pembelajaran tersebut. Berdasarkan hasil wawancarawawancara tersebut dapat dilihat dari diagram-diagram berikut ini;

Sinyal internet dirumah

30 jawaban

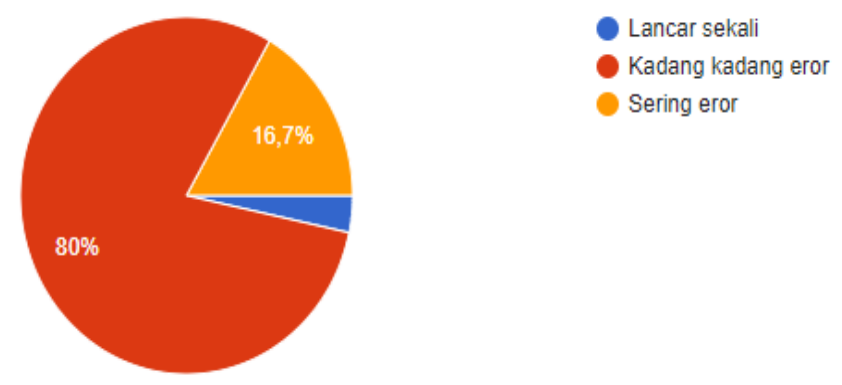

\section{Diagram 1. Presentase sinyal internet di rumah}

Keterangan; dari diagram terkait sinyal internet di rumah terlihat $80 \%$ kadang-kadang errror, $16,7 \%$ lancar, dan 3,3\% lancar

\section{Apakah sudah memiliki hp sendiri}

30 jawaban
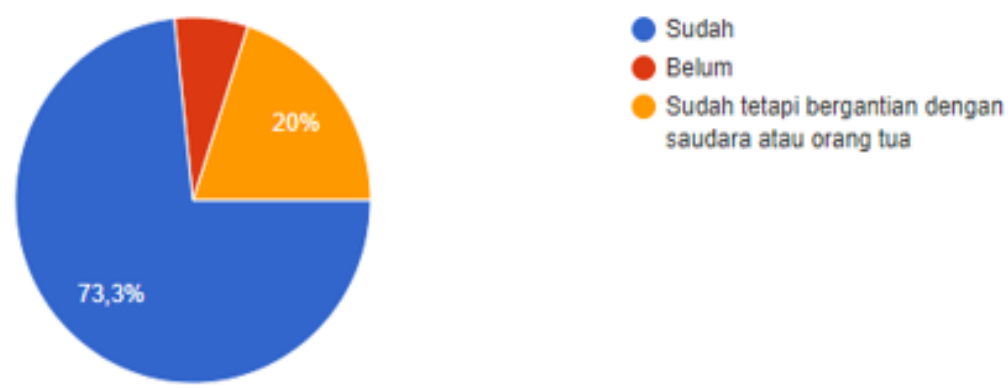

Diagram 2. Prosentase kepemilikan hp

Keterangan; dari diagram terkait apakah sudah memiliki hp sendiri terlihat 73,3\% sudah memiliki, 20,0\% sudah memiliki tetapi bergantian dengan saudara atau orang tua, dan $6,7 \%$ belum memiliki hp.

Apakah orang tua membantu dalam kegiatan belajar daring

30 jawaban

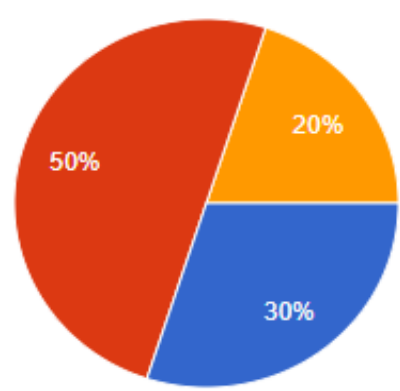

Membantu

Kadang kadang Membantu

Tidak membantu

Diagram 3. Prosentase apakah orang tua membantu dalam kegiatan belajar daring 
Keterangan; dari diagram apakah orang tua membantu dalam kegiatan belajar daring terlihat 50\% kadang-kadang membantu, 30\% membantu, dan 20\% membantu.

Apakah orang tua memahami materi yang diajarkan di pembelajaran daring

30 jawaban

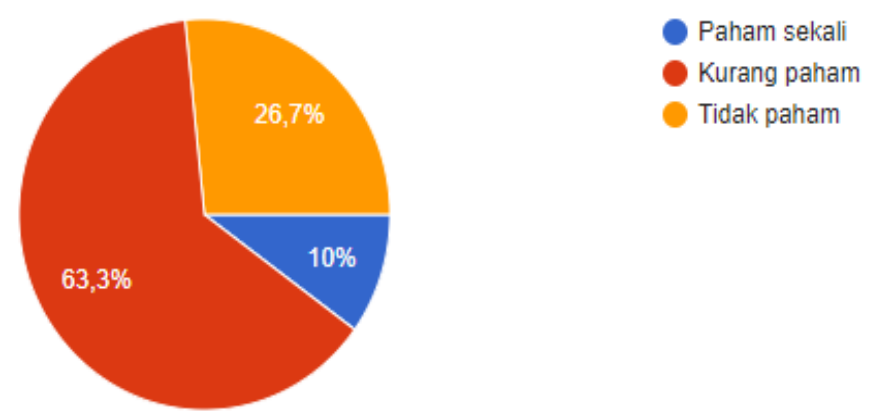

\section{Diagram 4. Prosentase apakah orang tua memahami materi yang diajarkan di pembelajaran daring}

Keterangan; dari diagram apakah orang tua memahami materi yang diajarkan di pembelajaran daring terlihat $63.3 \%$ kurang paham, 26,7\% tidak paham, dan $10 \%$ paham sekali.

Apakah orang tua memahami aplikasi yang dipake dalam pembelajaran daring

30 jawaban

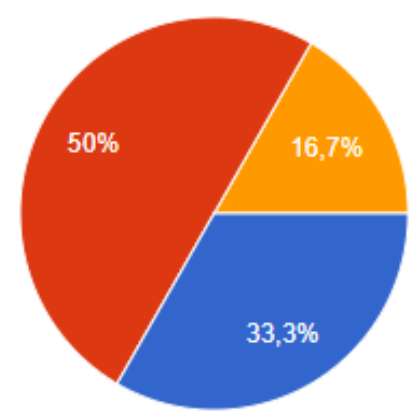

Tidak paham

Diagram 5. Prosentase apakah orang tua memahami aplikasi yang dipakai dalam pembelajaran daring

Keterangan; dari diagram apakah orang tua memahami aplikasi yang dipakai dalam pembelajaran daring terlihat 50\% kurang paham, 33,3\% paham sekali, dan 16,7\% tidak paham 
Pendidikan terakhir ayah

30 jawaban

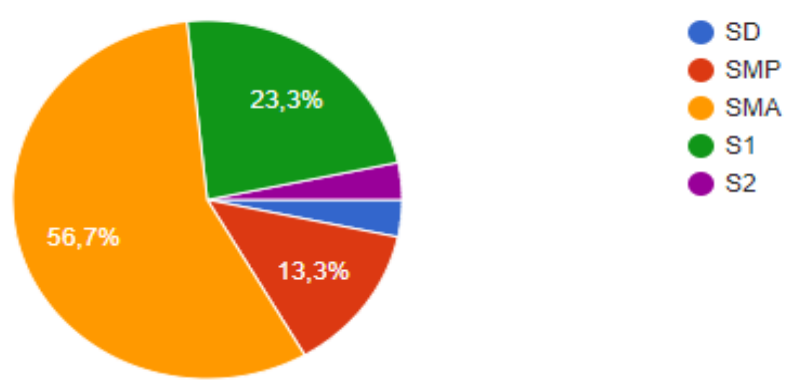

Diagram 6. Prosentase tingkat pendidikan terakhir Ayah

Keterangan; dari diagram terkait tingkat pendidikan Ayah terlihat 56,7\% SMA, 23,3\% S1, dan 13,3\% SMP, 3,35 \% SD, 3.35\% S2.

Pendidikan terakhir ibu

30 jawaban

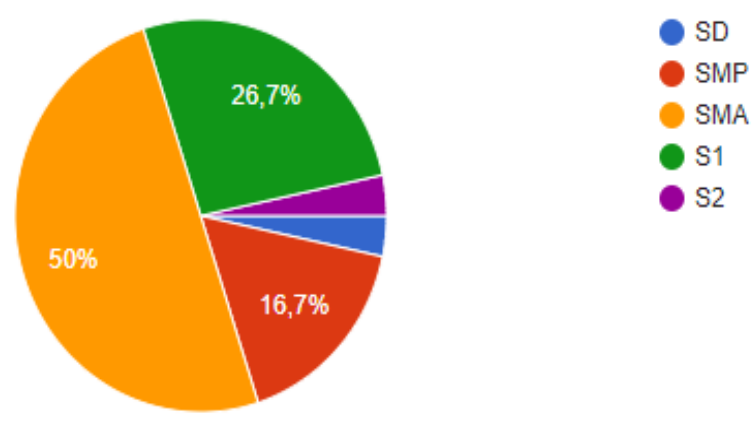

\section{Diagram 7. Prosentase tingkat pendidikan terakhir Ibu}

Keterangan; dari diagram terkait tingkat pendidikan Ibu terlihat 50\% SMA, 26,7\% S1, dan $16,7 \%$ SMP, $3,3 \%$ SD, $3.3 \%$ S2.

\section{Ayah}

30 jawaban

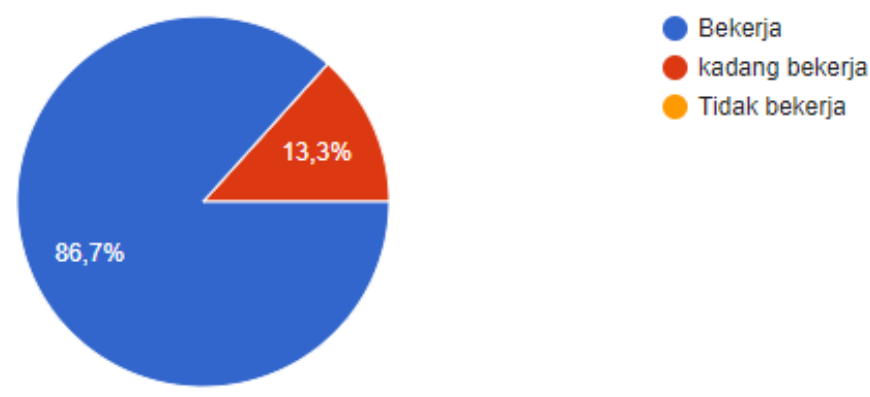

Diagram 8. Prosentase status pekerjaan Ayah

Keterangan; dari diagram terkait status pekerjaan Ayah terlihat 86,7\% bekerja, 13,3\% kadang-kadang bekerja. 
lbu

30 jawaban

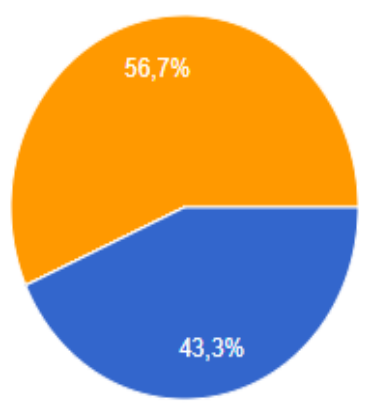

Bekerja

kadang bekerja

tidak bekerja

\section{Diagram 9. Prosentase status pekerjaan Ibu} bekerja.

Keterangan; dari diagram terkait status pekerjaan Ibu terlihat 56,7\% tidak bekerja, 43,3,

Pembelajaran daring harus ada peran serta orang tua di dalamnya. Berkaitan dengan hal itu maka akan dibahas terkait kendala dan peran orang tua pada pembelajaran daring di masa pandemi covid-19 dalam terlihat hasil aktual di lapangan sebagai berikut;

1. Orang tua /wali hanya sesekali mendampingi anaknya, karena orang tua juga tidak mengerti atau paham akan materi tersebut. Jadi hanya sekadar mengingatkan saja, terkait tugasnya sudah dikerjakan atau belum. Berkaitan dengan hal itu, sinyal internet juga terkadang susah. Sinyal internet yang terkadang susah tentu menghambat jalannya pembelajaran. Beberapa hasil wawancara tersebut dapat disimpulkan terdapat berbagai macam kendala yang dihadapi orang tua pada proses pembelajaran yang dilakukan di rumah

2. Mulai dari jaringan internet yang terkadang susah, hal ini tentu sangat menghambat proses pembelajaran. Bahkan ada siswa yang hanphonenya harus bergantian,sehingga tidak bisa tertib dalam mengumpulkan tugas. Begitu banyak tugas yang diberikan membuat siswa jenuh bahkan stres

3. Orang tua yang sibuk bekerja, anak menjadi kurang diperhatikan, sehingga prestasi belajar anak menurun

4. Orang tua yang hanya salah satu saja yang bekerja juga merasa terbebani akan hal ini karena dalam satu keluarga jenjang pendidikan anaknya di rumah berbeda. Orang tua yang tingkat pendidikannya berbeda beda, dan tentunya materi pembelajaran yang dialami dahulu dengan sekarang berbeda, tidak banyak orang tua pahami. Hasilnya apa yang diajarkan oleh anaknya sesuai dengan kemampuan orang tuanya

Peran Orang Tua Dalam Pembelajaran Daring Pada Masa Pandemi Covid-19 Dukungan orang tua dan semangat untuk kegiatan belajar di rumah dan didukung dengan keterlibatan guru pada pemberian materi belajar sangat penting untuk keberlangsungan pendidikan anak. Hal ini didukung dengan semakin banyak pendapat ahli menyatakan bahwa membangun relasi yang baik antara anak, orang tua, dan sekolah dalam mendukung proses pembelajaran, mampu memberikan hal positif dalam pembelajaran, dan dibarengi dengan hasil belajar yang lebih baik. Seperti diketahui bahwa orang tua adalah pendidik utama bagi anaknya (Etika,2020). Menurut (Ahmadi, 2004: 43) menyatakan peran orang tua sangat penting. Orang tua adalah guru pertama yang dimiliki oleh anak. Baik buruknya anak banyak dipengaruhi oleh pola asuh orang tua. Oleh karena itu tanggung jawab orang tua sangat kompleks. Berbagai aspek menjadi tanggung jawabnya, mulai dari pendidikan, gaya hidup. Pendidikan juga bukan hanya formal saja, pendidikan non formal juga menjadi tanggung jawab orang tua. Bagaimana cara agar orang tua dapat mendidik anaknya dengan baik dan benar, agar mampu menhdapai tantangan yang akan datang. 
Konsep pembelajaran jarak jauh memaksa orang tua untuk dapat menggunakan teknologi. Karena orang tua akan mengajarkan teknologi tersebut kepada anaknya. Orang tua harus kreatif dan inovatif dalam menyiapkan pelaksanaan pebelajaran daring dan memberikan bimbingan atau tuntunan kepada anak agar dapat memanfaatkan akses teknologi modern dalam proses pembelajaran yang nantinya juga akan meningkatkan kualitas dari anak itu sendiri (Prasojo \& Riyanto, 2011). Prestasi belajar dengan sistem belajar dari rumah lebih banyak ditentukan oleh peran orang tua. Menangapi hal itu orang tua harus mampu memberikan perannya yang terbaik. Misalnya penjadwalan dalam belajar, menerapkan kedisiplinan yang lebih.

Memberikan reward jika anak berhasil menengerjakan tugas dengan baik. Apabila menemui kesulitan dalam pemahaman materi, segera melakukan komunikasi dengan guru yang bersangkutan. Orang tua harus senatiasa menjalin hubungan yang baik kepada semua guru, hal ini mendukung proses pembelajaran. Dengan tindakan itu anak menjadi lebih terarah dalam belajar, walaupun orang tua kurang memahami materi tersebut.

Melakukan evaluasi, bagaimana hasil belajar anak apakah sudah baik. Jika belum baik, hal apa yang perlu dibenahi. Intensitas belajaranya ataukah hal lain. Selalu memberikan motivasi kepada anak. Jangan memarahi atau bahkan memberikan hukuman jika anak tidak bisa atau kurang memahami materi pelajaran.

Peran orang tua sangat diperlukan. Orang tua bukan hanya sekadar pemenuh kebutuhan finansial, namun bimbingan-bimbingan inilah yang lebih penting untuk perkembangan anak. Jika hal ini tidak seimbang atau bahkan tidak diberikan maka tumbuh kembang anak menjadi kurang. Selain berdampak pada prestasi hasil belajar, karakter yang dimiliki anak akan menjadi kurang baik.

\section{KESIMPULAN}

Pandemi covid-19 membuat dunia pendidikan harus bergerak cepat, salah satunya dengan pembelajaran daring. Agar pembelajaran tetap berjalan dan memutus mata rantai penyebaran virus. Peran serta orang tua tidak bisa lepas akan hal ini sehingga dibutuhkannya motivaasi terhadap anak untuk bisa tetap bersemangat sekolah walapun secara daring. orang tua dituntut mampu membimbing anak di rumah, begitupun dengan siswa. Siswa dituntut untuk memahami materi yang disampaikan dan menyelesaikan tugas yang diberikan oleh guru. Diperlukannya kordinasi yang baik juga antara orang tua dan guru.

Langkah terakhir yaitu diadakannya evaluasi agar hasil belajar anak meningkat. Berbagai kendala yang dihadapi orang tua pada pembelajaran daring diantaranya: (1) sinyal internet yang terkadang susah dan eror; (2) kuota yang terbatas; (2) orang tua /wali belum mendampingi sepenuhnya anaknya; (3) Orang tua belum memahami materi, sehingga tidak bisa maksimal dalam mengajari anak; (4) Handphone yang salinmg bergantian antar saudara.

\section{DAFTAR PUSTAKA}

Ahmadi, Abu. (2004). Sosiologi Pendidikan. Jakarta: Rineka Cipta.

Etika ,W.U. (2020). Kendala dan Peran Orangtua Dalam Pembelajaran Daring Pada Masa Pandemi. Semarang : Universitas Negeri Semarang

Khadijah, \& Gusman. (2020). Pola Kerja Sama Guru dan Orang tua Mengelola Bermain Aud Selama Masa Pandemi Covid-19. Jurnal Kumara Cendekia. Vol 8 (2), 154170.

Lutfiah, S., Z. (2020). Persepsi Orang Tua Mengenai Pembelajaran Online Di Rumah Selama Pandemi Covid-19. Jurnal Dealektik. Vol. 2 (2) 2655-8491.

Prasojo, Lantip Diat, \& Riyanto. (2011). Teknologi Informasi Pendidikan. Yogyakarta: Gava Media.

Sarwono, Jonathan. (2006). Metode Penelitian Kuantiatif dan Kualitatif. Yogyakarta: Graha Ilmu.

Sudaryanto. (1993). Metode Dan Aneka Teknik Analisis Bahasa (Pengantar Penelitian Wahana Kebudayaan Secara Linguistis). Yogyakarta: Duta Wacana University Press. 
Sujarweni, Wiratna, V. (2014). Metodologi Penelitian. Yogyakarta: Pustaka Baru Press.

Wardhani, T., Z \& Hetty, Y. (2020). Optimalisasi Peran Pengawasan Orang Tua Dalam Pelaksanaan Sekolah Online Di Masa Pandemi Covid-19. Prosiding Penelitian \& Pengabdian Kepada Masyarakat Vol 7 (1), 48 - 59.

Zahrok, S., \& Suarmini, N. W. (2018). Peran Perempuan dalam Keluarga. Journal of Proceedings Series 